\title{
Tracing the Development of Student's Argumentation in Science Classroom: Knowledge Acquisition and Motivation
}

\author{
Riezky Maya Probosari $^{1}$, Fatma Widyastuti ${ }^{1}$, Sajidan $^{1}$, Suranto ${ }^{1}$, Baskoro Adi Prayitno ${ }^{1}$ \\ ${ }^{1}$ Science Education Doctoral Program, Faculty of Teacher Training and Education, Universitas \\ Sebelas Maret, Jalan Ir. Sutami No. 36A, Surakarta, Indonesia
}

\begin{abstract}
This empirical study on 4th- semester students' argumentation performance in biology education program is reported. This research aims to find out how was the students constructing and building their own argument in many scientific cases, the way they reform knowledge and maintain their motivation related to their community. Through a classroom research, argumentation skills such as how they declare claim, find the data, build the reason and justify their point of view were analyzed. An intervention was done to foster their argumentation, specifically in strengthen their prior knowledge through reading science text. The results showed that the argumentation process and products increased as they experienced in citing research article and doing scientific communication in the class. The implication for best practice in teaching scientific argumentation is discussed.
\end{abstract}

Keywords: Scientific argumentation; prior knowledge; knowledge acquisition; motivation

\section{INTRODUCTION}

Science and argument are two things that can not be separated [1,2]. Arguments in science teaching plays a very important role because in the essence science learning aims not only to master of scientific concept, but also actively involve students to reconstruct scientific knowledge more meaningfully [2-5]. The practice of argumentation begins when the student is on a problem, responding to a statement on a clear basis and maintaining or changing his or her position if there is a stronger foundation (6-8]. Every student has their own thoughts and through of the practice of argumentation, the statement will be selected, which category of "possible" is accepted, which includes "impossible", "probable" or "presumably"[9-11].

Scientific argumentation is a linguistic social process used to get a settlement of controversy of opinion by each person who exposes the reason of the action they choose [12]. In solving a problem, a person must provide a statement supported by evidence or reason. The settlement is justified through argumentation to reveal reasoning skills and high-level thinking skills that others have [13]. This is what makes arguments can be used as an indicator of cognitive ability that leads to high-level thinking skills. In other words, a person who has the argument and not just arguing means having good critical thinking and logic. 
In this study, students' progress in constructing and building their own argument in many scientific cases were investigated, and also determined the way they reform their knowledge and maintain motivation in arguing.

\section{ARGUMENTION PRACTICE IN HIGHER EDUCATION}

Involving students to be actively committed in argumentation as part of scientific communication within the scope of higher education requires the ability of sensitivity, experience, background, knowledge, and understanding the situation accordance with deductive and informal logic [14] so they can determine their respective positions, whether to accept, reject or even alter the statements of others or themselves. It should be distinguished whether a communication is included in the category of argumentation or simply the delivery of ideas only. Some practice of argument in higher education has been done and experienced in the last decade. Some researchers argue that the practice of argumentation is generally done collaboratively through actual scholarly dialogue or through argumentative writing [11,15-18]. The argumentation skill between children and adults basically has the same characteristics, regardless of the complexity of the issues in question. The child is considered to be able to argue if it states an argument underlying a particular statement or claim $[19,20]$, understand the structure of the argument correctly [5,21], actively involved in class discussions [22,23]. In the perspective of the development of cognitive ability, the activity of argument in the scope of higher education is different, especially in terms of epistemological understanding through the coordination of subjective and objective knowledge dimensions [24].

In practice, the essence of argumentation in science education refers not to how students defend, support or contradict others, but rather aim at how students construct knowledge together $[15,25]$. The integration of scientific attitude and insight become main focus in the implementation of scientific argumentation. Habituation of argumentation learning encourages students to view the problem explicitly and critically and foster an inquiry attitude to test the validity of their respective views [26], how they formulate opinions, objections or contradictions within appropriate theoretical and practice frameworks. The existence of controversy or contradictions is an inseparable part of the argument, but ultimately the student realizes that knowledge construction will never be derived from subjective prejudices or opinions [24,27] .

\section{SYSTEMIZING ARGUMENTATION}

Arguments are the process of connecting data and information to generate a powerful and appropriate idea or idea and are used to study science information to improve students' ability to explain the cause of events. This will also affect the ability of students to build a new scientific knowledge, comprehension and build a good mentality in argue $[9,28,29]$.

The skills of scientific argument are divided into several aspects, namely: 1) claim, as an affirmation of what is being learned or the values being retained; 2) data, is a statement used as evidence to support the claim; 3) warrant, is a statement that explains the relationship of data with claim; 4) backing, statements used to strengthen warrants; 
5) qualifier, which raises the power ratio of claim data by warrant; and 6) rebuttal, is a statement of rebuttal or statement contrary to claim, data, warrant, backing or qualifier $[9,28,30]$. Scientific argumentation requires not only the structure of logical reasoning, but also should contain logical content.

\section{METHODS}

This study applied a qualitative methods research design through classroom research [31,32] to explore students' argumentation skill and took place in a 2nd-grade biology education classroom in a state university in Central Java and taught by team members. The participants were 29 students ( 24 females and 4 males) who had taken plant anatomy class. They are not experienced with related communication, especially on how to build scientific arguments to convince others. Based on the previous observation, the class discussion has been dominated by only a few students, and most of them rely on lecturer as their major learning resource.

Data were taken during the eight-week period from students' argumentative writing assignments and oral presentation. Data used to capture students' argumentation activities and how they develop their argument. Intervention by lectures was done in two weeks, to develop students' knowledge of scientific argumentation and practice. intervention is done by lecturers to improve students' written argumentation skills through proper selection of references for scientific papers and good scientific argumentation principles. Intervention is done in 2 meetings. Furthermore, each student presents an improved paper in front of the class and gives the other students some opportunities to ask questions, refute or change their initial statement after an argument with their friend.

\section{RESULTS AND DISSCUSSION}

Findings showed several facts from the data: (1) students' argumentation profile, (2) students' argumentation style, (3) student's argumentative discourse, (4) positioning in the end of argumentation. Table I provides students' proportion argumentation in writing as follows :

\section{TABLE I. STUDENTS' PROPORTION ARGUMENTATIVE WRITING SCORE AND TIME}

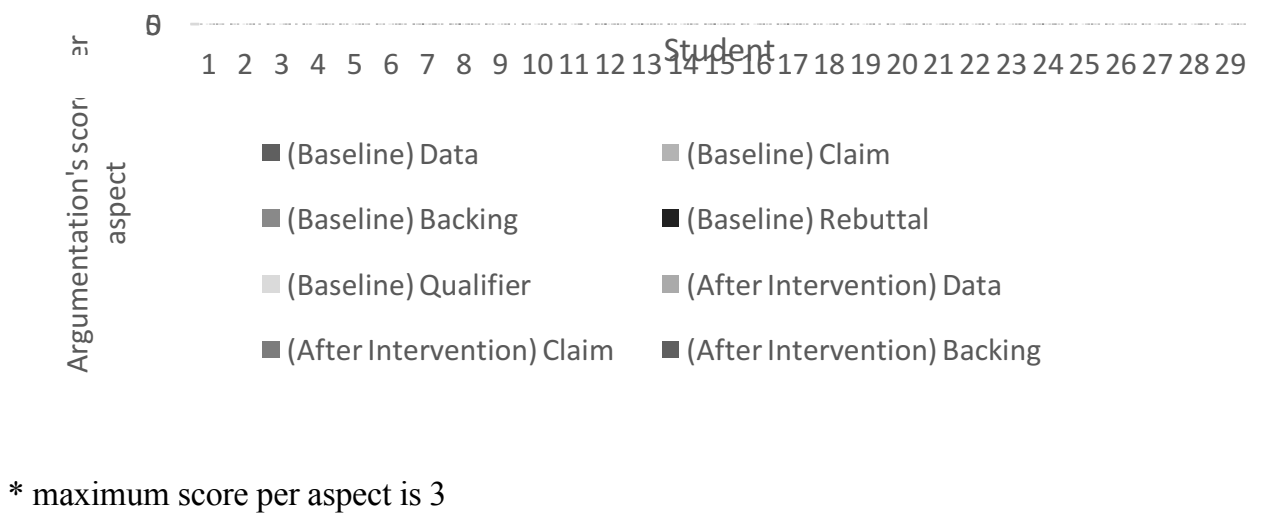


From all of 29 students who made argumentative writing, it found that overall the total written argumentation score of all students increased compared to the baseline. Initially, all students formulated their claim first, then they look for data related to the statement. It makes the argumentation seems weak because the most claim is still categorized as opinion, consequently they should find the data in accordance with the statement. The different fact was shown after the intervention, ie students formulate the statement after they actually perform empirical or theoretical tests through data that has been justified from accurate research. In other words, not a claim that then directs the data, but from the data, we can make a claim $[9,28]$.

Related to argumentation writing skills, all students use their references to formulate claims and show evidence of previous research data. However, only a few could use proper references to formulate their warrants, rebuttal, and qualifiers, whereas a good scientific argumentation was built on the structure of entire claim, evidence or data, warrant, rebuttal and qualifier $[9,28,33,34]$. The next mistake is another misconception of the argumentation structure. Students often have misinterpreted categorizing of backing, warrant, qualifier, and rebuttal so that the reasons given are ambiguous.

The practice of argumentation is conducted in the form of a presentation discussion. Each student presents the results of their argumentative writing and must defend the arguments they made. The results of the students' performance are presented in Table II belows :

TABLE II. STUDENTS’ PERFORMANCE ON ARGUMENTATION DISCOURSE

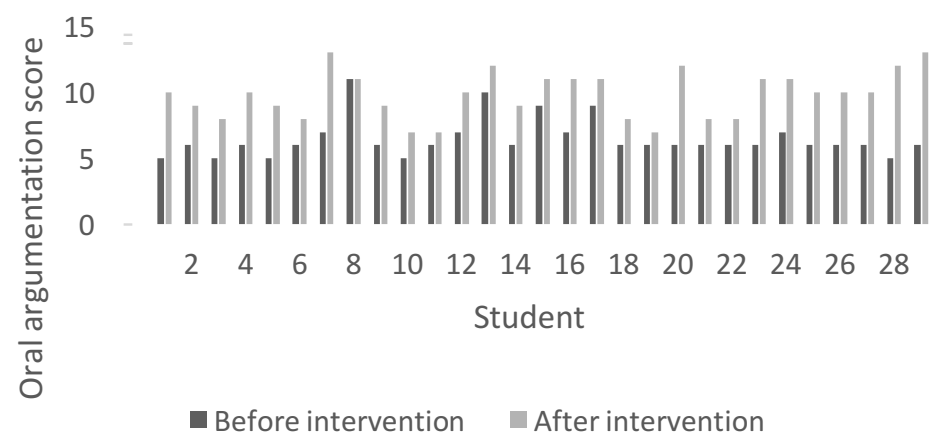

*maximum total score is 15

Oral argumentation scores include aspects of data, evidence, backing, qualifier, and rebuttal. All students were increased in all argumentation aspects except in the student no. 8 even though the scores obtained were well categorized because it was in 11 score range from 15. Not all students could reach the rebuttal stage, either before or after the intervention. It can happen because rebuttal is the most complicated aspect of argument and requires better mastery of concepts and empirical evidence because not all research results can be broken easily without a strong foundation [35]. In addition, the ability of the student qualifier also increases, evidenced by the increasing number of "most likely" phrases compared to "possible". In terms of maintaining their argument, the student's position is illustrated in Table III as follows : 
TABLE III. STUDENTS’ POSITIONING IN THE END OF DISCUSSION

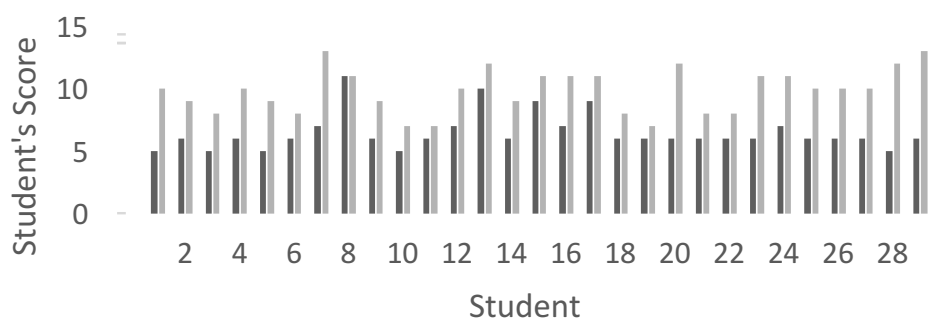

- Before intervention After intervention

From 29 students, initially there were only two students who successfully defended their arguments, but after the intervention, there were 10 students who successfully defended their statements, while the rest had to change the statement because it could be broken by other friends' arguments. The result of the interview showed that 10 students turned out to have more up to date references than others. This fact also related to the ability of the English language because students who have good ability in reading and understand English science articles showed better citation skills to be a strong basis for arguing.

Argument plays a crucial role in the development of critical thinking skills and builds a deeper understanding of various complex issues. The results of this study prove that teaching students to argue is not an easy matter, because many students and even adults have difficulty to distinguish what arguments and what are the reasons, Students often fail to identify parts of the argument such as problem formulation, reasoning, and evidence, or unable to present it in class discourse [36-38]. Efforts to stimulate the practice, skills and understanding of arguments in learning take a long time, through habituation and should be sustainable [39,40], however, it also has not ensured that students are willing and able to develop the practice of argumentation in all of the material they get $[24,41,42]$ so it needs an integrative and continues efforts to familiarize students to argue.

\section{CONCLUSIONS}

The lack of scientific argumentation skills before the intervention was largely due to the lack of conceptual knowledge of the students. It can be anticipated by strengthening previous and basic scientific knowledge through the use of appropriate research article literature. The results showed that the argumentation process and products are growing in scientific research in the class. Students stated that their argument ability improved after participated in the interactive discussion in the classroom, comparing their statements with other opinions. The main problem that is not solved yet is how to deliver best practice in teaching argumentation according to the various capability of students, especially with different language skills so further exploration needs to be done in the argumentation practice in the science classroom. 


\section{REFERENCES}

[1] Christodoulou A, Osborne J. The science classroom as a site of epistemic talk: A case study of a teacher's attempts to teach science based on argument. J Res Sci Teach. 2014;51(10).

[2] Erduran S, Jiménez-Aleixandre MP. Argumentation in Science Education. Erduran S, JiménezAleixandre MP, editors. Netherlands: Springer; 2007.

[3] Macagno F. A Means-End Classification of Argumentation Schemes. In: van Eemeren FH, Garssen B, editors. Reflections on Theoretical Issues in Argumentation Theory. London: Springer International Publishing; 2015. p. 183-201.

[4] Jin H, Mehl CE, Lan DH. Developing an analytical framework for argumentation on energy consumption issues. J Res Sci Teach. 2015;52(8).

[5] Chen YC, Lin JL, Chen YT. Teaching Scientific Core Ideas through Immersing Students in Argument: Using Density as an Example. Sci Act Classr Proj Curric Ideas. 2014;51(3):78-88.

[6] Freeman JB. Identifying the Warrant of an Argument. In: Reflections on Theoretical Issues in Argumentation Theory. London: Springer International Publishing; 2015. p. 93-106.

[7] Fox J, Modgil S. From Arguments To Decisions : Extending the Toulmin View. In: Arguing on the Toulmin Model New Essays in Argument Analysis and Evaluation. Netherlands: Springer; 2006. p. 273-87.

[8] McNeill KL. Elementary students' views of explanation, argumentation, and evidence, and their abilities to construct arguments over the school year. J Res Sci Teach. 2011;48(7):793-823.

[9] Toulmin SE. The Uses of Argument. Cambridge: Cambridge University Press; 2003.

[10] Kuhn D, Udell W. The Development of Argument Skills. Child Dev. 2003;74(5):1245-60.

[11] Kuhn D, Hemberger L, Khait V. Dialogic argumentation as a bridge to argumentative thinking and writing. Infanc y Aprendiz. 2016;39(1):25-48.

[12] Rigotti E, Morasso SG. Argumentation as an Object of Interest and as a Social and Cultural Resource. In: Mirza NM, Perret-Clermont A-N, editors. Argumentation and Education: Theoretical Foundations and Practices. London: Springer US; 2009. p. 9-67.

[13] Jonassen DH. Learning to Solve Problems: An Instructional Design Guide. San Fransisco: Pfeiffer; 2004.

[14] Ennis RH. Probably. In: Arguing on the Toulmin Model: New Essays in Argument Analysis and Evaluation. Dordrecht: Springer; 2006. p. 145-64.

[15] Andriessen JEB. Argumentation in Higher Education: Examples of Actual Practices with Argumentation Tools. In: Mirza NM, Perret-Clermont AN, editors. Argumentation and Education: Theoretical Foundations and Practices. New York: Springer; 2009. p. 195-214.

[16] Clark DB, Sampson V, Chang H-Y, Zhang H, Tate ED, Schwendimann B. Research on Critique and Argumentation from the Technology Enhanced Learning in Science Center. In: Khine MS, editor. Perspectives on Scientific Argumentation: Theory, Practice and Research. Springer Netherlands; 2014. p. 157-99.

[17] Probosari RM, Sajidan, Suranto, Prayitno BA. Dampak inkuiri berjenjang terhadap dimensi literasi sains calon guru biologi. In: Prosiding Seminar Biologi. Surakarta; 2016. p. 450-4.

[18] Nussbaum EM. Argumentation, Dialogue Theory, and Probability Modeling: Alternative Frameworks for Argumentation Research in Education. Educ Psychol. 2011;46(2):84-106.

[19] Garcia-Mila M, Anderson C. Cognitive foundations of learning argumentation. In: Erduran S, Jimenez-Aleixandre MP, editors. Argumentation in science education: Perspectives from classroom-based research. Netherlands: Springer; 2007. p. 29-45.

[20] Chen YC, Hand B, Park S. Examining Elementary Students??? Development of Oral and Written Argumentation Practices Through Argument-Based Inquiry. Sci Educ. 2016;25(34):277-320.

[21] Horng R-Y, Lu P-H, Chen P-H, Hou S-H. The Effects of Argument Stance on Scientific Knowledge Inquiry Skills. Int J Sci Educ. 2013;35:2784-2800.

[22] Duschl R a., Osborne J. Supporting and Promoting Argumentation Discourse in Science Education. Stud Sci Educ. 2002;38(1):39-72.

[23] Nyström E. Teacher talk: producing, resisting and challenging discourses about the science classroom. Gend Educ. 2009;21(6):735-51.

[24] Berland LK, Reiser BJ. Making Sense of Argumentation and Explanation. Sci Educ. 2008;93, Issue(1):26-55.

[25] Hunter A. Towards Higher Impact Argumentation. Knowl Creat Diffus Util. 2004;(2):275-80. 
[26] Mirza NM, Perret-Clermont AN, Tartas V, Iannaccone A. Psychosocial Processes in Argumentation. In: Mirza NM, Perret-Clermont AN, editors. Argumentation and Education: Theoretical Foundations and Practices. New York: Springer US; 2009. p. 67-90.

[27] Bricker LA, Bell P. Argumentation and Reasoning in Life and in School: Implications for the Design of School Science Learning Environments. In: Khine MS, editor. Perspectives on Scientific Argumentation: Theory, Practice and Research. Netherlands: Springer Netherlands; 2012. p. 117-32.

[28] Hitchcock D, Verheij B. Arguing on the Toulmin Model : New Essays in Argument Analysis and Evaluation. Vol. 10, Argumentation Library. 2006.

[29] Pluijm LC, Visser JC. David Hitchcock and Bart Verheij (eds): Arguing on the Toulmin Model. New Essays in Argument Analysis and Evaluation. Argumentation. 2011;25(4):527-39.

[30] Verheij B. Evaluating Arguments Based on Toulmin's Scheme. Argumentation. 2006;19(3):347-71.

[31] Creswell JW. Research Design: Qualitative, Quantitative, and Mixed Methods Approaches. Research design Qualitative quantitative and mixed methods approaches. California: SAGE Publication; 2014. 398 p.

[32] Creswell JW. Qualitaive Inquiry and Reseach Desgin: Choosing Among Five Approaches. London: SAGE Publication; 2007.

[33] Woods J. Eight Theses Reflecting on Stephen Toulmin. In: Arguing on the Toulmin Model New Essays in Argument Analysis and Evaluation. Dordrecht: Springer; 2006. p. 379-97.

[34] Nielsen JA. Arguing from Nature: The role of "nature" in students' argumentations on a socioscientific issue. Int J Sci Educ. 2012;34(5):723-44.

[35] Frey BB, Ellis JD, Bulgren JA, Hare JC, Ault M. Development of a Test of Scientific Argumentation. Electron J Sci Educ. 2015;19(4).

[36] Chen YC, Hand B, Park S. Examining Elementary Students' Development of Oral and Written Argumentation Practices Through Argument-Based Inquiry. Sci Educ. 2016;25(3-4):277-320.

[37] Deane P. Writing Assessment and Cognition. Educational Testing Service. New Jersey; 2011.

[38] Deane P, Song Y. A case study in principled assessment design: Designing assessments to measure and support the development of argumentative reading and writing skills. Psicol Educ. 2014;20(2):99-108.

[39] Chen Y, Yarker MB, Chen Y, Benus MJ, Yarker MB. Using Models to Support Argumentation in the Science Classroom Using Models to Support. 2016;(September).

[40] Van Lacum EB, Ossevoort MA, Goedhart MJ. A teaching strategy with a focus on argumentation to improve undergraduate students' ability to read research articles. CBE Life Sci Educ. 2014;13(2):253-64.

[41] Kuhn D, Hemberger L, Khait V. Tracing the Development of Argumentive Writing in a Discourse-Rich Context. Writ Commun. 2016;33(1):92-121.

[42] Mayweg-paus E, Kuhn D, Mayweg-paus FME, Kuhn D. Argumentation Theory in Education Studies : Coding and Improving Students ' Argumentative Strategies Argumentation Theory in Education Studies: Coding and Improving Students' Argumentative Strategies. Topoi. 2015;34:523-37. 